\title{
PENINGKATAN KUALITAS LAYANAN BERBASIS PEMUSTAKA: Sebuah Paradigma Baru Pengukuran Kinerja Perpustakaan
}

\author{
RM Endhar Priyo Utomo \\ Universitas Diponegoro Semarang, Jawa Tengah, Indonesia \\ endhar@undip.ac.id
}

\begin{abstract}
Today's development, there has been a paradigm shift from the concept applied by the library. This change occurs by placing users as centers of all activities carried out by the library. This is certainly different from the previous concept which placed the library as the center of all the activities it did. Libraries as service providers must begin to realize that they are influenced by a competitive situation. The existence of a quality-oriented service seeks to identify gaps between expected services and services received by users. The existence of this change has become a demand for customers as customers from the library. The improvement in service quality will lead to an increase in the performance of a library. With the increase in the level of satisfaction of the users, it is expected that it will encourage the loyalty of the users.
\end{abstract}

Keywords: quality of service, library performance, library users 


\begin{abstract}
Abstrak
Perkembangan dewasa ini, telah terjadi sebuah perubahan paradigma dari konsep yang diterapkan oleh perpustakaan. Perubahan ini terjadi dengan menempatkan pemustaka sebagai center dari semua kegiatan yang dilakukan oleh perpustakaan. Hal ini tentunya berbeda dari konsep sebelumnya yang menempatkan perpustakaan sebagai center dari semua kegiatan yang dilakukannya. Perpustakaan sebagai penyedia jasa layanan, harus mulai menyadari bahwa dirinya dipengaruhi oleh sebuah situasi yang kompetitif, Adanya sebuah layanan yang berorientasi pada kualitas berusaha untuk mengidentifikasi kesenjangan antara layanan yang diharapkan dengan layanan yang diterima oleh pemustaka. Adanya perubahan ini telah menjadi tuntutan bagi pemustaka sebagai customer dari perpustakaan. Adanya peningkatan kualitas layanan, akan menyebabkan meningkatnya kinerja dari sebuah perpustakaan. Dengan adanya peningkatan tingkat kepuasan dari pemustaka, diharapkan akan dapat mendorong adanya loyalitas dari para pemustaka.
\end{abstract}

Kata kunci: kualitas layanan, kinerja perpustakaan, pengguna perpustakaan

\title{
A. Pendahuluan
}

Adanya ungkapan konsumen adalah raja, telah menjadi sebuah konsep yang telah lama berkembang di dalam dunia pemasaran. Oleh karena itu, sebuah perusahaan yang mencari keuntungan akan berusaha untuk memberikan layanan yang baik agar dapat memberikan kepuasan bagi konsumennya. Sebuah perusahaan menghasilkan produk ataupun jasa ditujukan untuk memenuhi kebutuhan dari konsumen dan konsumen akan membayar atas manfaat yang telah diperoleh atas produk atau jasa yang dinikmati. Sebagai produsen yang baik, tentunya sebuah perusahaan akan menghasilkan produk atau jasa sesuai dengan keinginan dari konsumennya. Memahami karakteristik dan keinginan dari konsumen merupakan sesuatu yang sangat 
fundamental dalam menentukan kerberhasilan pemasaran dari suatu produk maupun jasa.

Adanya penerapan konsep pemasaran seperti tersebut di atas, juga telah terjadi di dunia perpustakaan. Meskipun dapat dikatakan bahwa perpustakaan adalah sebagai organisasi nirlaba, perpustakaan dituntut untuk cerdas membidik konsumennya untuk mau menggunakan "produk" yang telah dihasilkannya. "Produk" yang dihasilkan oleh perpustakaan dalam hal ini adalah berupa jasa layanan yang diberikan kepada konsumennya. Di samping itu, perpustakaan juga dituntut harus jeli untuk menentukan segmentasi pasar dari konsumen yang dilayani. Hal ini agar tidak terjadi kesalahan dalam menyediakan jasa layanan yang diperlukan oleh konsumennya. Konsumen yang dimaksud di sini adalah pemustaka yang memanfaatkan layanan di perpustakaan.

Sebagai sebuah organisasi nirlaba, terkadang perpustakaan tidak terlalu memperhatikan kualitas dari "produk" yang dihasilkan. Hal ini tentunya akan dapat menyebabkan menurunnya tingkat kepuasan konsumen yang menggunakan "produk" dari perpustakaan. Perpustakaan terkadang hanya berpikir tentang lengkapnya koleksi yang dimilikinya saja, tanpa mencoba untuk berpikir bagaimana sebuah koleksi yang dimiliki dapat dimanfaatkan dengan baik oleh konsumennya. Koleksi yang dimiliki oleh sebuah perpustakaan dapat dikatakan sebagai sebuah investasi penting yang harus dapat "dijual" kepada konsumen untuk dapat memberikan manfaat yang seluas-luasnya. Sebuah perpustakaan yang paham akan hal ini, tentunya akan mulai berpikir untuk memperhatikan kualitas dari "produk" yang dihasilkannya. Selain itu adanya sebuah kompetisi dari berbagai penyedia sumber informasi dan tingginya harapan dari pemustaka akan kualitas layanan yang diberikan, seharusnya juga mendorong perpustakaan sebagai penyedia sumber informasi untuk lebih meningkatkan kualitas layanan yang diberikan kepada pemustaka. ${ }^{1}$

${ }^{1}$ Ashok Kumar Sahu, "Perception of Service Quality in Academic Library: A CAse Study," Journal of Services Research 6, no. 1 (September 2006): 
Perkembangan dewasa ini, telah terjadi sebuah perubahan paradigma dari konsep yang diterapkan oleh perpustakaan. Perubahan ini terjadi dengan menempatkan pemustaka sebagai center dari semua kegiatan yang dilakukan oleh perpustakaan. Hal ini tentunya berbeda dari konsep sebelumnya yang menempatkan perpustakaan sebagai center dari semua kegiatan yang dilakukannya.

Saat ini telah banyak penelitian yang mengungkapkan tentang pentingnya peningkatan kualitas layanan di perpustakaan. Dengan adanya peningkatan kualitas layanan layanan di perpustakaan maka akan dapat mendorong meningkatnya kepuasan dari pemustaka sehingga menciptakan loyalitas dari pemustaka untuk tetap memanfaatkan perpustakaan sebagai penyedia sumber informasi yang dibutuhkannya.

Dari uraian - uraian yang telah diungkapkan di atas, akan dapat muncul sebuah pertanyaan bagi kita semua, yaitu bagaimanakah konsep untuk mengukur sebuah kualitas

layanan yang ada di perpustakaan. Atas dasar pertanyaan tersebut itulah tulisan ini dibuat.

\section{Pengertian Layanan Perpustakaan}

Sebelum kita memahami tentang konsep kualitas layanan, terlebih dahulu kita harus memahami tentang layanan perpustakaan. Dengan kita dapat memahami tentang pengertian dari layanan perpustakaan, maka kita akan dapat menyusun sebuah konsep tentang kualitas layanan di perpustakaan.

Sebagaimana kita ketahui semua, tujuan dari sebuah perpustakaan adalah untuk mengusahakan agar koleksi yang ada di perpustakaan dapat dimanfaatkan secara maksimal oleh pemustaka. Usaha yang dilakukan oleh perpustakaan inilah yang disebut dengan layanan perpustakaan. Dengan kata lain layanan dapat diberikan pengertian sebagai sebuah kegiatan yang ada di perpustakaan yang menghubungkan antara sumber informasi yang

187. 
ada di perpustakaan dengan pemustaka sebagai pengguna dari sumber informasi tersebut.

Sebagai bagian dari kegiatan di perpustakaan, dapat dikatakan bahwa layanan perpustakaan merupakan elemen penting dalam menunjang kinerja dari sebuah perpustakaan. Dari kegiatan inilah tingkat kepuasan dari pemustaka dapat diukur. Merupakan suatu hal yang prinsip di dunia lembaga pusat dokumentasi dan informasi termasuk perpustakaan bahwa keberhasilan dari layanan merupakan salah satu indikator keberhasilan lembaga informasi atau perpustakaan dalam menjalankan fungsi dan tugasnya. ${ }^{2}$

Dengan melihat kenyataan seperti tersebut di atas, maka adanya layanan yang berkualitas menjadi sangat penting untuk disediakan perpustakaan sebagai penyedia sumber informasi yang dibutuhkan oleh pemustaka.

\section{Pengertian Kualitas Layanan di Perpustakaan}

Sebelum kita memahami tentang dimensi kualitas layanan, terlebih dahulu kita memahami pengertian dari kualitas itu sendiri. Terdapat beberapa ahli yang mengungkapkan pengertian mengenai kualitas. Juran mendefinisikan kualitas sebagai fitness for use. ${ }^{3}$ Sedangkan Begum mendefinisikan quality is customer satisfaction through product or by service. ${ }^{4}$

Konsep kualitas layanan dalam konteks perpustakaan dapat didefinisikan sebagai sebuah perbedaan antara harapan pengguna dengan persepsi kinerja layanan. ${ }^{5}$ Sedangkan Parasuraman dan Zeithmal mendefinisikan kualitas layanan sebagai tingkat ketidaksesuaian antara harapan atau keinginan konsumen dengan tingkat persepsi mereka (Zeithaml, Parasuraman, \& Bery, 1990)6 Selain itu, di dalam

${ }^{2}$ Suriani, Layanan Pengguna Berbasis Total Quality Service (Jogjakarta: Jurusan Ilmu Perpustakaan dan Informasi Fakultas Adab Universitas Islam Negeri Sunan Kalijaga, 2006).

${ }^{3}$ Suriani.

${ }^{4}$ S Siraj Nissa Begum, "Total Quality Management in The Academic Library," Library Philosophy and Practice Vol.5, no. 2 (2003): 36.

${ }^{5}$ Ashok Kumar Sahu, "Perception of Service Quality in Academic Library: A CAse Study," 187.

${ }^{6}$ (Zeithaml, Parasuraman, \& Bery, 1990) 
perpustkaan kualitas juga dapat diberikan pengertian sebagai kecepatan dalam pengiriman atau berkurangnya suatu kesalahan dalam sebuah layanan. ${ }^{7}$ Kualitas juga dapat dilihat sebagai segala sesuatu yang berkaitan dengan kesesuaian layanan atau produk seperti yang diinginkan dalam tujuan atau pengguna. Adanya sebuah kualitas haruslah dapat memberikan kenyamanan bagi pelanggan dalam memenuhi kebutuhannya. Maksudnya di sini adalah kualitas layanan dapat didefinsikan persepsi pelanggan terhadap apa yang baik atau buruk, diterima atau tidak diterimanya layanan

Brophy menyebutkan bahwa kualitas merupakan hal yang senantiasa berhubungan dengan kepuasan pelanggan. Sedangkan pakar lain juga memberikan definisi kualitasdengan penekanan yang berbeda. Di antaranya oleh Goetsch dan Davisyangmendifinisikan kualitas sebagai kondisi dinamis yang berhubungan dengan produk, jasa, manusia, proses dan lingkungan yang memenuhi atau melebihi harapan.

Terdapat dua definisi kualitas yang secara luas diterima, yaitu quality is conformance tothe customer's requirements danquality is fitness for the customer's purpose. ${ }^{8}$ Dari duadefinisi tersebut menekankan pelanggan yang dalam hal ini adalah pemustaka adalah focus pertimbangan dari adanya sebuah kualitas.

Dari beberapa pengertian yang telah diungkapkan di atas dapat ditarik sebuah benang merah bahwa bahwa pelanggan dapat dikatakan puas dengan layanan yang diberikan (kinerja layanan) jika terdapat kesesuaian antara yang diterima dengan apa yang dharapkan, demikian juga sebaliknya.

Dalam literatur perpustakaan, konsep kualitas belum berkembang dengan baik, tergantung pada konteks di mana suatu organisasi perpustakaan berusaha untuk menilai kualitas

${ }^{7}$ Susan B. Barnard, "Implementing Total Quality Management:" Journal of Library Administration 18, no. 1-2 (13 Juli 1993): 59, https://doi. org/10.1300/J111v18n01_05.

${ }^{8}$ Ashok Kumar Sahu, "Perception of Service Quality in Academic Library : A CAse Study," 187. 
pelayanannya.. Adanya penilaian seberapa baik perpustakaan berhasil tergantung pada pemustaka sebagai "hakim" kualitas. Tujuan utama dari setiap perpustakaan karenanya harus memaksimalkan kepuasan pengguna dan untuk melampaui harapan. Kualitas layanan akan dapat menjadi sebuah masalah yang besar ketika perpustakaan mencoba untuk memperluas cakupannya dan meningkatkan layanannya.

\section{Peningkatan Kualitas Layanan di Perpustakaan.}

Perpustakaan sebagai penyedia jasa layanan, harus mulai menyadari bahwa dirinya dipengaruhi oleh sebuah situasi yang kompetitif, Adanya sebuah layanan yang berorientasi pada kualitas berusaha untuk mengidentifikasi kesenjangan antara layananyang diharapkan dengan layanan yang diterima oleh pemustaka. Dalam hal ini layanan memilki dua aspek, ${ }^{9}$ yaitu

1. Functional quality, artinya perpustakaan dengan fungsinya sebagai sumber informasi perlu melengkapi koleksinya secara terus menerus dan terbaru.

2. Technical quality, artinya perpustakaan perlu memiliki sumber daya dengan kualitas teknis yang baik, mengaplikasikan akses ke teknoli informasi yang relevan dan menunjukkan sikap melayani dan terampil dalam melakukannya.

Pada bagian sebelumnya telah dijelaskan bahwa tolak ukur dari kualitas layanan perpustakaan adalah adanya kepuasan dari pemustaka sebagai pelanggan. Perpustakaan sebagai pihak yang memberikan layanan kepada pemustaka, terkadang mengalami kesulitan dalam mengukur tingkat kualitas layanan yang telah diberikan. Hal ini disebabkan karena terdapat perbedaan tingkat kepuasan dari pemustaka yang memanfaatkan layanan di perpustakaan. Zeithaml, Parasuraman dan Berry menetapkan

${ }^{9}$ Septiantoro T., Dasar Dasar Ilmu Perpustakaan (Jogjakarta: Jurusan Ilmu Perpustakaan dan Informasi Fakultas Adab Universitas Islam Negeri Sunan Kalijaga, 2006). 
5hal yang dapat digunakan untuk mengukur kualitas layanan sebagaimana yang diharapkan oleh pelanggan. ${ }^{10}$ Menurut mereka, kualitas layanan dapat diukur dari hal-hal sebagaimana berikut :

1. Tangibles (Nyata), meliputi bagian-bagian pelayanan yang bersifat nyata/langsungseperti penampilan karyawan, fasilitas fisik, peralatan, , sarana komunikasi.

2. Realibility (Kehandalan), yakni kemampuan memberikan layanan yang dijanjikandengan segera, akurat dan memuaskan.

3. Responsiveness (Kesigapan/Tanggap), yaitu keinginan para staf untuk membantupara pelanggan dan menyediakan pelayanan secara cepat dan tepat, serta tanggap terhadap keinginan konsumen.

4. Assurance (Jaminan atau Kepastian), mencakup tingkat pengetahuan dankeramahan tamahan serta sopan santun yang harus dimiliki karyawan

5. Empathy (Empati), merupakan perhatian khusus yang diberikan kepada setiappelanggan secara individu. Dimensi empati merupakan gabungan dari dimensi:

Sementara itu Parasuraman sendiri mengungkapkan bahwa terdapat 10 dimensi yang dapat dipergunakan untuk mengukur kualitas layanan. ${ }^{11}$ Menurutnya, kualitas layanan diukur dari halhal berikut :

1. Reliabilitas, yaitu adanya konsistensi kinerja dan dependensi pelayanan

2. Responsivitas, yaitu adanya kemampuan dan kesiapan petugas dalam memberikan layanan

${ }^{10}$ Valaire A. Zeithaml, A. Parasuman, dan Leonard L. Berry, "Servqual : A Multiple - Item Scale for Measuraing Consumer Perception of Service Quality," Journal of Retailing Vol. 64, No. 1 (1988): 15.

${ }^{11}$ Valerie A. Zeithaml, A. Parasuman, dan Leonard L. Berry, Delivery Service Quality: Balancing Consumer and Expectation (New York: The Free Press, 1990). 
3. Kompetensi, yaitu petugas memiliki keterampilan dan pengetahuan untuk melakukanpelayanan

4. Akses, yaitu adanya kemudahan untuk memanfaatkan jasa yang ditawarkan.

5. Courtecy, artinya ada kesopanan, rasa hormat, ramah, dan penuh pertimbangan

6. Komunikasi, yaitu adanya kemampuan melakukan komunikasi untuk

7. menyampaikan informasi kepada pelanggan atau memperoleh masukan dari pelanggan.

8. Kredibilitas, yaitu meliputi hal-hal yang berhubungan dengan kepercayaan kepada organisasi seperti reputasi, prestasi, dsb.

9. Keamanan, yaitu tidak adanya bahaya, resiko atau keraguan untuk menggunakan jasa yang ditawarkan.

10. Pengertian, yaitu meliputi usaha untuk mengetahui dan memahami kebutuhan dan keinginan pelanggan

11. Ada yang terlihat, yaitu adanya bukti fisik dari pelayanan yang disajikan

Karakteristik pengukuran akan kualitas antara sebuah perusahaan yang menghasilkan jasa dan yang menghasilkan produk memiliki perbedaan. Bahkan antara penyedia jasa saja juga memiliki kekhususan, misalnya karakteristik jasa perbankan berbeda dengan jasa pendidikan. Demikian juga dengan perpustakaan juga memiliki kekhasan.

Banyak pakar menentukan karakter kualitas organisasi perpustakaan.. Salah satunya adalah yang telah dikemukakan di atas. Association of Research Library (ARL) memodifikasi apa yang telah dilakukan oleh Parasuraman menjadi Library Quality(LIBQual) (Cook, 2001). ${ }^{12}$ Secara ringkas pengukuran kualitas layanan dapat dijelaskan dalam tabelberikut di bawah ini.

\footnotetext{
${ }^{12}$ Collen Cook dan Fred M. Heath, "Users Perception Of Library Service Quality : A LIBQUAL Qualitative Study," ARL Measuring Service Quality
} 


\begin{tabular}{ll}
\hline \multicolumn{1}{c}{ Parasuraman } & \multicolumn{1}{c}{ LibQual } \\
\hline Tangiable & Perpustakaan sebagai tempat \\
\hline Reliability & Keandalan \\
\hline Responsiveness & Pengaruh layanan \\
\hline Assurance & Akses informasi \\
\hline Emphaty & Kelengkapan koleksi \\
\hline
\end{tabular}

Gambar 1. Karakteristik Kualitas Jasa Perpustakaan diolah dari berbagai sumber

Apabila karakteristik kualitas layanan perpustakaan sebagaimana yang digunakan oleh Association of Research Library (ARL) yang dinamakan libQual, maka karakteristik kualitas layanan perpustakaan seperti gambar di bawah ini

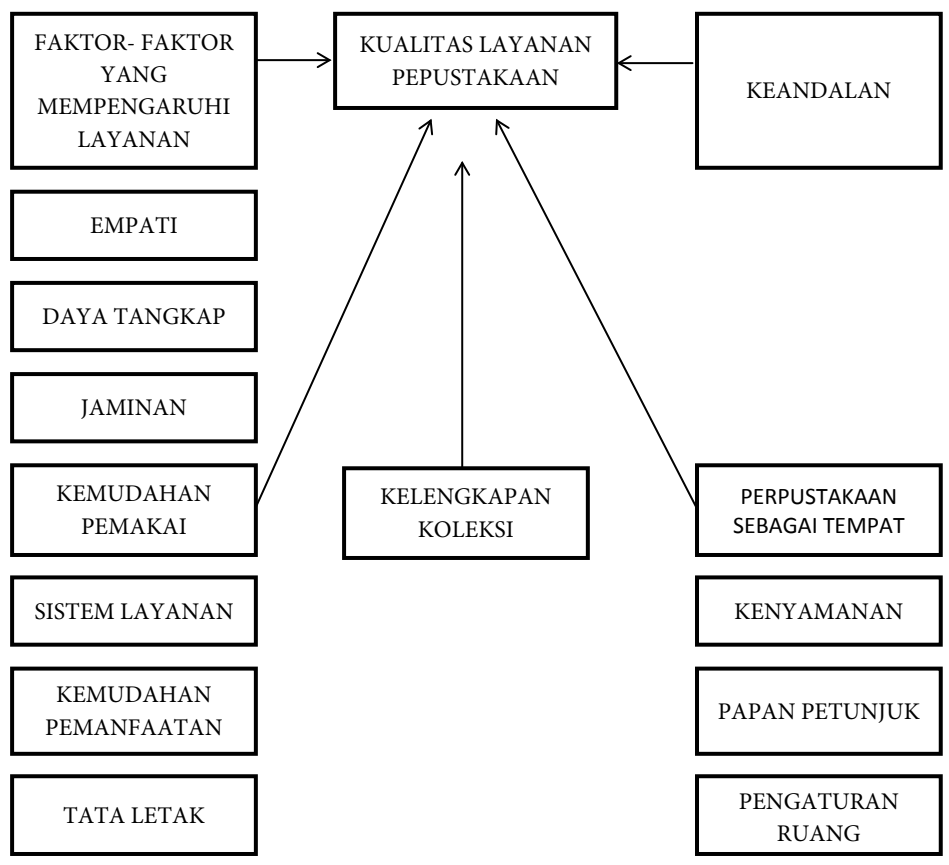

Gambar 2. Karakteristik Kualitas Jasa Layanan Perpustakaan ${ }^{13}$

Symposium, 2001, 21.

${ }^{13}$ Collen Cook dan Fred M. Heath, 2008. 
Berikut uraian penjelasan dari gambar di atas.

1. Faktor-faktor yang mempengaruhi Layanan

a. Empati

Yaitu suatu sikap, respon dan tindakan dimana pustakawan dapat merasakan apa yang sedang dirasakan oleh pemakai. Pemakai datang ke perpustakaan tentunya bermaksud mencari buku yang dibutuhkan, maka semaksimalnya apa yang dibutuhkan pemakai dapat terpenuhi. Ada kalanya pemakai datang untuk sekedar mencari kenyamanan dan ketenangan, maka pustakawan mencoba mengkondisikan apa yang dirasakan oleh pemakai.

b. Daya Tanggap (Responsiveness)

Salah satu ciri seorang profesional adalah memiliki daya tanggap yang cepat atau responsif. Pemakai akan sangat terkenang dengan respon cepat dari pustakawan atas kebutuhan yang dihadapinya.

c. Jaminan (Assurance)

Yang termasuk jaminan antara lain kemampuan, kesopanan, sifat yang dapat dipercaya oleh pustakawan, sehingga pemakai akan merasa nyaman dalam memanfaatkan layanan perpustakaan.

2. Keandalan (Reliability)

Kemampuan pustakawan untuk memberikan layanan sesuai yang dijanjikan dengan akurat, cepat dan memuaskan. Misalnya untuk satu kali transaksi peminjaman bila standar waktunya 30 detik/transaksi, maka maksimal waktu 30 detik itu yang harus diberikan kepada pemakai. Perpustakaan memiliki standar operasional dalam setiap jenis layanan, misalnya pengolahan buku dari sejak buku datang sampai siap dipinjam oleh pemakai memerlukan waktu berapa hari. Standar tersebut dikomunikasikan kepada pemakai. 
3. Kemudahan Pemakaian

a. Jenis Layanan

Pemakai akan lebih menyukai perpustakaan yang menggunakan sistem layanan terbuka. Pemakai secara psikologis lebih senang bila tahu betul keberadaan bahan pustaka yang diinginkan. Pada sistem layanan tertutup, kecurigaan pemakai kepada pustakawan untuk bersikap adil dalam melayani pemakai selalu ada. Sistem layanan terbuka lebih memungkinkan interaksi yang lebih mendalam antara pustakawan dan pemakai.

b. Kemudahan pemanfaatan

Kemudahan menggunakan seluruh fasilitas perpustakaan dengan membuat aturan yang mudah dipahami, jelas dan tidak birokratis. Peraturan yang terkesan diadaadakan dan semboyan bila-bisa dipersulit mengapa dipermudah harus dijauhkan.

c. Tata letak

Tata letak di sini lebih difokuskan kepada penempatan perabotan dan perlengkapan agar pemakai mudah menggunakan koleksi perpustakaan.Perabotan yang ergonomis sangat membantu kenyaman pemakai.

4. Kelengkapan Koleksi

Kelengkapan koleksi merupakan salah satu faktor utama pendorong masyarakat berkunjung dan memanfaatkan layanan perpustakaan. Survey di empat perpustakaan universitas terkemuka di Australia menunjukkan dari 40 item harapan terhadap layanan perpustakaan, koleksi yang sesuai dengan kebutuhan pemakai menempati urutan ketiga. Peran bagian pengembangan koleksi sangat penting untuk memajukan perpustakaan. 
5. Perpustakaan sebagai tempat

a. Kenyamanan

Sebagian besar orang kalau ditanya mengenai perpustakaan, maka jawabannya biasanya tempat menyimpan buku. Posisioning perpustakaan sebagai tempat buku atau gudang buku masih kuat tertancap dibenak pikiran masyarakat. Lebih ironis lagi gedung perpustakaan dipersepsikan kotor, tua, berdebu dan statis.Fasilitas dan kegunaan perpustakaan yang lain menjadi tidak berarti. Pendapat seperti di atas harus segera diluruskan.Tempat yang nyaman, teduh, bersih dan membuat betah merupakan prioritas sebuah perpustakaan. Gedung perpustakaan juga harus lebih dinamis dalam merespon aktifitas pegawai dalam melayani pemakai, maupun kebutuhan tambahan pemakai. Ruangan dan aktifitas tambahan di luar kegiatan utama kepustakawanan tersebut, antara lain: ada ruang untuk diskusi kecil maupun seminar, aula yang besar, jika perlu terdapat ruang pamer benda seni atau fotografi.

b. Papan petunjuk

Denah dimana perpustakaan berada, penting diberikan. Petunjuk arah ditempatkan di lokasi yang strategis sehingga pemakai mudah menemukannya.Denah di dalam gedung juga perlu diperhatikan, apalagi biasanya gedung perpustakaan memiliki banyak lantai. Kemudahan pemakai mendapatkan yang dibutuhkan sangat membantu kenyaman pemakai.

c. Pengaturan ruangan

Ruangan yang tertata baik dan fungsional akan memudahkan pegawai maupun pengunjung dalam memenuhi kebutuhannya. Pengaturan ruangan yang baik sangat mempengaruhi tingkat intensitas kunjungan 
pemakai. Penggunaan konsultan disain interior maupun eksterior dalam derajat tertentu jauh lebih efektif dan efisien.

Dari uraian-uraian di atas telah dijelaskan berbagai pengukuran yang dapat dipergunakan untuk mengetahui peningkatan kualitas layanan yang diberikan oleh perpustakaan kepada pemustaka. Layanan yang berkualitas seharusnya tidak hanya berhenti setelah pemustaka meninggalkan perpustakaan, tetapi harus selalu diciptakan secara terus menerus sebagai suatu kontinuitas kegiatan di perpustakaan. Sebagai sebuahelemen kegiatan di perpustakaan, layanan yang ada harus menekankan kepada kepentingan pemustaka sebagai customer dari perpustakaan. Terdapat konsep pemasaran yang dapat dilakukan oleh perpustakaan untuk menunjang peningkatan kualitas layanan di perpustakaan. Adapun konsep tersebut adalah sebagai berikut:

1. Put yourself in your customer shoes

Untuk mengetahui apa yang dibutuhkan konsumen dan apa yang diinginkan, kita harus mencoba dan merasakan sebagai konsumen.

2. Customer is the bos

Konsumen adalah bos sehingga kita harus melayaninya dengan baik karena pada dasarnya konsumen itu ingin merasa bahagia jika tujuannya tercapai serta tidak ingin dibebani dengan bermacam-macam urusan.

3. Customer is the profit everything else is overhead

Kita harus memberikan pelayanan yang melebihi dari apa yang diharapkan oleh konsumen. Hal itu akan membuat konsumen loyal untuk terus menjadi konsumen yang baik.

4. Customer is business, business is people, people are customer

Karena merupakan suatu lingkaran, kita yang harus menentukan sendiri layanan kita agar kita tidak ditinggalkan oleh konsumen kita 
Dengan kita menerapkan lima hal di atas, diharapkan perpustakaan akan dapat selalu meningkatkan kualitas layanan yang diberikan kepada pemustaka. Dengan adanya peningkatan kualitas layanan akan memberikan dampak terhadap meningkatnya kepuasan pemustaka ketika memanfaatkan layanan yang ada di perpustakaan. Adanya kepuasan dari pemustaka, diharapkan juga akan dapat menciptakan loyalitas dari pemustaka untuk selalu memanfaatkan layanan yang disediakan oleh perpustakaan.

\section{B. Penutup}

Dari uraian-uraian di atas dapat diketahui bahwa saat ini telah terjadi perubahan dalam pengukuran kinerja perpustakaan. Pengukuran kinerja perpustakaan yang dulunya masih sebatas menyangkut ketersediaan koleksi, kini telah berubah kepada penilaian kualitas layanan yang diberikan oleh perpustakaan.

Adanya perubahan ini telah menjadi tuntutan bagi pemustaka sebagai customer dari perpustakaan. Adanya peningkatan kualitas layanan, akan menyebabkan meningkatnya kinerja dari sebuah perpustakaan. Dengan adanya peningkatan tingkat kepuasan dari pemustaka, diharapkan akan dapat mendorong adanya loyalitas dari para pemustaka. 


\section{DAFTAR PUSTAKA}

Barnard, Susan B. "Implementing Total Quality Management:" Journal of Library Administration 18, no. 1-2 (13 Juli 1993): 57-70. https://doi.org/10.1300/J111v18n01_05.

Begum, S Siraj Nissa. "Total Quality Management in The Academic Library." Library Philosophy and Practice Vol.5, no. 2 (2003).

Cook, Collen, dan Fred M. Heath. "Users Perception Of Library Service Quality: A LIBQUAL Qualitative Study." ARL Measuring Service Quality Symposium, 2001.

Sahu, Ashok Kumar. "Perception of Service Quality in Academic Library : A CAse Study." Journal of Services Research 6, no. 1 (September 2006).

Septiantoro T. Dasar Dasar Ilmu Perpustakaan. Jogjakarta: Jurusan Ilmu Perpustakaan dan Informasi Fakultas Adab Universitas Islam Negeri Sunan Kalijaga, 2006.

Suriani. Layanan Pengguna Berbasis Total Quality Service. Jogjakarta: Jurusan Ilmu Perpustakaan dan Informasi Fakultas Adab Universitas Islam Negeri Sunan Kalijaga, 2006.

Zeithaml, Valaire A., A. Parasuman, dan Leonard L. Berry. "Servqual: A Multiple - Item Scale for Measuraing Consumer Perception of Service Quality." Journal of Retailing Vol. 64, No. 1 (1988).

Zeithaml, Valerie A., A. Parasuman, dan Leonard L. Berry. Delivery Service Quality: Balancing Consumer and Expectation. New York: The Free Press, 1990. 